\title{
PERBANDINGAN PARAMETER ATMOSFER RADIOSONDE DI PALEMBANG DAN PANGKALPINANG SELAMA INTENSIVE OBSERVATION PERIODE (IOP)
}

\author{
A Comparison of Radiosonde-Based Atmospheric Paramaters \\ Measurements in Palembang and Pangkalpinang During an Intensive \\ Observation Periode (IOP)
}

\author{
Ibnu Athoillah ${ }^{1)^{\star}}$, Rini Mariana Sibarani ${ }^{1)}$ \\ 1) Balai Besar Teknologi Modifikasi Cuaca - Badan Pengkajian dan Penerapan Teknologi, Gedung Ir. \\ Mohammad Soebagio, GEOSTECH (820), Kawasan PUSPIPTEK, Serpong, Tangerang Selatan \\ ${ }^{*}$ E-mail : ibnu.athoillah@bppt.go.id
}

\begin{abstract}
Intisari
Beberapa kondisi udara atas yang bagus untuk mendukung pertumbuhan awan adalah udara dalam kondisi labil, kelembapan yang cukup basah dan angin yang tidak terlalu kencang. Profil udara atas ini biasa diukur dengan menggunakan radiosonde. Namun selama ini terjadi keterbatasan dalam hal lokasi peluncuran radiosonde yang tidak banyak di Indonesia, seperti di Palembang tidak ada peluncuran radiosonde yang rutin dilakukan kecuali ada event tertentu seperti Intensive Observation Period (IOP) sehingga dalam kondisi biasa untuk mengetahui profil udara atasnya menggunakan lokasi peluncuran radiosonde terdekat yaitu di Pangkalpinang. Penelitian ini bertujuan untuk membandingkan parameter dari pengukuran radiosonde Palembang saat kegiatan IOP dengan radiosonde Pangkalpinang, guna mengetahui apakah parameter yang dihasilkan dari radiosonde Pangkalpinang bisa digunakan untuk wilayah Palembang. Parameter yang dibandingkan adalah KIndex, Lifted Index, Showalter Index, Convective Temperature (TC), CAPE, RH $850 \mathrm{mb}, \mathrm{RH} 700 \mathrm{mb}$ dan RH $500 \mathrm{mb}$. Perbandingan dilakukan secara visual dan uji statistik. Secara visual dengan metode grafik dan secara statistik menggunakan Wilcoxon Signed Rank Test. Hasil secara visual menunjukkan semua parameter memiliki pola yang mirip dan berdekatan. Hasil uji statistik menunjukkan hampir semua parameter yang diuji memiliki nilai probabilitas di atas 0.05 yang berati tidak ada perbedaan yang signifikan antara hasil pengukuran di Palembang dan Pangkalpinang kecuali parameter Showalter Index yang memiliki nilai probabilitas 0.008 atau di bawah 0.05 yang menunjukkan bahwa parameter Showalter Index ini ada perbedaan yang signifikan dari kedua lokasi.
\end{abstract}

Kata Kunci : Radiosonde, Wilcoxon Signed Rank Test, Profil Udara Atas.

\begin{abstract}
Several upper air conditions that are conducive in support of clouds growths are unstable air, high humidity and mild wind. The upper air profile/conditions is usually measured by using radiosonde. But there have been limitations with respect to radiosonde launch locations which are not that widespread in Indonesia. For example, in Palembang, there are no routine radiosonde launches unless there were certain events such as an Intensive Observation Period (IOP). Thus, under normal conditions, in order to identify the upper air profile, the closest radiosonde launch is conducted in Pangkalpinang. This study aims to compare parameters from radiosonde measurement in Palembang during IOP with parameters measured from a radiosonde launch in Pangkalpinang in order to determine whether or not the parameters measured in Pangkalpinang can be applied to measurements conducted in the Palembang area. The compared parameters are K-Index, Lifted Index, Showalter Index, Convective Temperature (Tc), CAPE, RH $850 \mathrm{mb}, \mathrm{RH} 700 \mathrm{mb}$ and RH 500 mb. Comparisons were done visually and statistically. Visually with a graphical method and statistically by using the Wilcoxon Signed Rank Test. The visual results shows all parameters having a similar and close pattern. While the statistical test result shows that almost all test parameters have a probability value of above 0.05 , which means there are no significant difference between the Measurements results conducted in Palembang and Pangkalpinang except for The Showalter Index parameter which has a probability value 0.008 or below 0.05 , indicating that the Showalter Index parameter has a significant difference from both locations.
\end{abstract}

Keywords : Radiosonde, Wilcoxon Signed Rank Test, Upper Air Profile. 


\section{PENDAHULUAN}

Keadaan udara atas memiliki karakteristik yang khas karena memiliki skala waktu dan ruang yang sempit jika dibandingkan dengan proses yang mempengaruhinya. Kebanyakan kejadian cuaca terjadi di lapisan atmosfer atas, mulai dari uap air yang terangkat, menjadi jenuh, berkondensasi, hingga jatuh menjadi titik hujan. Dengan gambaran atmosfer yang lebih lengkap akan diperoleh pemahaman keadaan atmosfer yang lebih baik, oleh karena itu diperlukan pengamatan terhadap udara atas untuk memahami keadaan atmosfer pada keadaan yang sebenarnya.

Beberapa kondisi udara atas yang bagus untuk mendukung pertumbuhan awan adalah udara dalam kondisi labil, kelembapan yang cukup basah dan angin yang tidak terlalu kencang. Profil udara atas ini biasa diukur dengan menggunakan radiosonde sehingga dapat diketahui dinamika serta kelembapan udara pada beberapa lapisan yang mendukung pembentukan dan pertumbuhan awan khususnya awan konvektif seperti profil tekanan udara, suhu lingkungan, kelembapan relatif, arah dan kecepatan angin serta indeks-indeks labilitas udara seperti K Index, Lifted Index dan Showalter Index.

Radiosonde adalah instrumen yang dilepaskan ke atmosfer dengan menggunakan balon yang berisi gas Helium atau Hidrogen untuk mengukur beberapa parameter cuaca seperti suhu, kelembapan, tekanan udara, serta arah dan kecepatan angin. Radiosonde ini dilengkapi dengan pemancar untuk mengirim data ke penerima di bumi (station). Radiosonde ini biasa dilepaskan dua kali dalam sehari yaitu pada pukul 00 UTC dan 12 UTC, kecuali pada saat-saat tertentu seperti dalam kegiatan Intensive Observation Periode (IOP) radiosonde ini bisa dilepaskan empat kali dalam sehari yaitu pukul 00 , 06, 12 dan 18 UTC.

Beberapa penelitian sebelumnya terkait parameter yang diperoleh dari radiosonde banyak digunakan untuk melihat potensi kondisi cuaca ke depan diantaranya penelitian dari Mayangwulan et al (2011) tentang potensi kejadian badai guntur berdasarkan kelembapan, labilitas udara dan mekanisme pengangkatan di Biak berdasarkan analisa statistik dengan model regresi logistik variabel precipitable water mempunyai korelasi dan berbanding lurus dengan kejadian badai guntur sedangkan TC mempunyai korelasi dan berbanding terbalik dengan kejadian badai guntur dan CAPE tidak mempunyai korelasi dengan kejadian badai guntur. Menurut penelitian Syaifullah (2011) berkaitan dengan pengamatan peluncuran radiosonde stasiun tabing dari Juni sampai November 2010 disimpulkan bahwa apabila indeks labilitas pada hari tersebut cukup baik maka peluang terjadinya presipitasi akan semakin besar. Selanjutnya Syaifullah (2017) juga mengamati peluncuran Radiosonde dari 11 titik stasiun peluncuran yang ada di Indonesia, Malaysia dan Singapura selama 5 tahun menyebutkan tentang indeks radiosonde CAPE yang cenderung lebih besar pada daerah dekat ekuator dibandingkan daerah yang jauh dari ekuator. Sementara peneltian dari Zahroh et al (2017) mengenai potensi hujan lebat yang disertai guntur dari data radiosonde dan radiometer menghasilkan terdapat perbedaan hasil sounding sebelum hujan dan pada saat hujan. Hasil sounding sebelum kejadian hujan memiliki labilitas moderat dan sounding pada saat kejadian hujan/badai guntur memiliki labilitas kuat.

Selama ini terjadi keterbatasan dalam hal lokasi peluncuran radiosonde yang tidak banyak di Indonesia. Di Indonesia peluncuran radiosonde biasanya berada di bandar udara yang dekat dengan kota-kota besar, sehingga terjadi keterbatasan dalam hal pengambilan data yang tidak ada di lokasi peluncuran radiosonde. Seperti dalam kasus ini akan diambil studi kasus di Palembang yang tidak ada peluncuran radiosonde dalam kondisi normal, sehingga dalam hal untuk mengetahui profil udara atas di Palembang menggunakan lokasi terdekat yang terdapat peluncuran radiosonde. Lokasi peluncuran radiosonde yang terdekat dengan kota Palembang adalah Pangkalpinang.

Dalam hal membandingkan dua data pengukuran dari dua tempat berbeda Juaeni (2017) telah melakukan penelitian mengenai perbandingan parameter atmosfer permukaan dari dua lokasi yaitu Padang dengan Selaparang dari Januari-Desember 2015 dengan menggunakan uji statistik Anova dengan hasil curah hujan bulan Maret dan temperatur serta kelembapan pada bulan April dari kedua lokasi cenderung sama dengan p-value 0.6-0.9. Ogungbenro \& Morakinyo (2014) melakukan penelitian dengan metode Wilcoxon untuk melihat apakah ada perbedaan hujan dalam 90 tahun terakhir di wilayah Nigeria, hasilnya menunjukkan nilai $p$-value $<0.05$ yang berarti ada variasi hujan di wilayah tersebut. Aprilina et al (2017) melakukan penelitian dengan metode WilcoxonMann Whitney untuk menguji perbedaan antara peralatan pengamatan otomatis dan manual di 12 stasiun pengamatan milik BMKG dengan hasil tidak ada beda nyata antara hasil pengukuran dari pengamatan otomatis maupun manual. Hua et al (2017) juga melakukan penelitian dengan metode Wilcoxon Signed Rank Test untuk mengestimasi suhu tahunan terpanas di Tibet dalam 1 dekade terakhir yang menghasilkan dalam 1 dekade terakhir tidak ada perbedaan suhu panas dalam satu dekade terakhir.

Dalam tulisan ini akan dibandingkan hasil pengukuran dari lokasi peluncuran radiosonde di Pangkalpinang dengan peluncuran radiosonde di Palembang pada saat Intensive Observation Period (IOP) yang nantinya diharapkan dari hasil penelitian ini dapat memvalidasi pemakaian 
radiosonde dari Pangkalpinang untuk melihat profil udara atas di wilayah Palembang.

Hipotesis awal dari penelitian ini adalah profil udara atas dari pengukuran radiosonde Pangkalpinang dapat menggambarkan profil udara atas di wilayah Palembang dikarenakan jarak antara kedua kota yang berdekatan. Hipotesis tersebut akan diuji apakah memang sama atau tidak ada perbedaan yang nyata untuk masing-masing parameter di kedua lokasi dengan Wilcoxon Signed Rank Test.

\section{METODE}

Palembang dan Pangkalpinang merupakan dua lokasi yang letaknya cukup berdekatan dengan jarak garis lurus sekitar $170 \mathrm{~km}$. selama ini data hasil peluncuran radiosonde yang rutin di wilayah Pangkalpinang bisa diakses melalui website http://weather.uwyo.edu/upperair/sounding.html, sementara untuk wilayah Palembang hanya saat tertentu saja dilakukan peluncuran radiosonde seperti pada saat kegiatan Intensive Observation Periode (IOP) yang dilakukan kerja sama antara BBTMC BPPT dan BMKG.

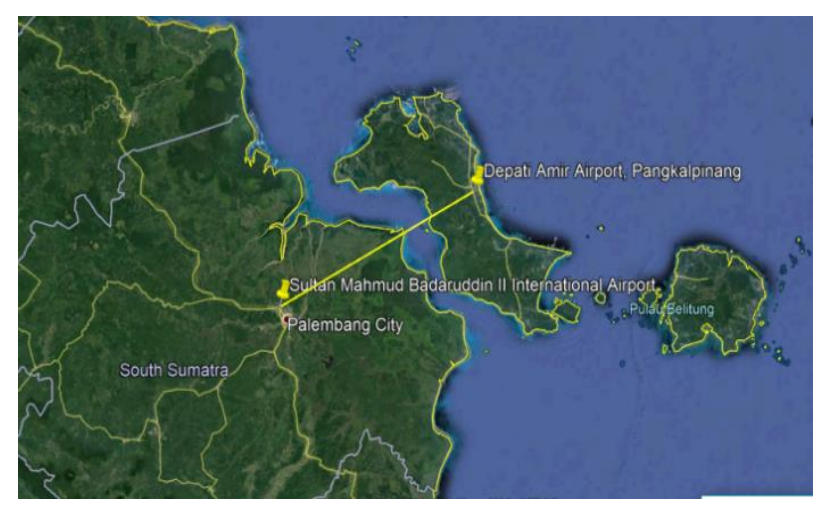

Gambar 1. Jarak lokasi penelitian antara Pelembang dan Pangkalpinang

Data pada saat kegiatan IOP akan digunakan dalam penelitian ini untuk melihat kemiripan atau kesamaan hasil antar profil udara atas di Pangkalpinang dan Palembang, yang nantinya akan digunakan untuk memvalidasi apakah data radiosonde dari Pangkalpinang dapat menggambarkan kondisi profil udara di wilayah Palembang.

Data periode pengamatan yang digunakan adalah pada saat kegiatan IOP yaitu tanggal $17 \mathrm{Juli}$ s.d 16 Agustus 2017, dengan mengambil data kelembapan relatif pada lapisan $850 \mathrm{mb}, 700 \mathrm{mb}$, $500 \mathrm{mb}$, TC (Convective Temperature), CAPE, $\mathrm{K}$ Index, Lifted Index, dan Showalter Index pada masing-masing lokasi dan jam peluncuran radiosonde pukul 00 dan 12 UTC.

Untuk menguji kesamaan hasil pengukuran radiosonde dari Pangkalpinang dan Palembang akan digunakan analisis Wilcoxon signed rank test. Penggunaan uji wilcoxon disebabkan karena data yang tidak berdistribusi normal.

\subsection{Indeks-Indeks Radiosonde}

Beberapa indeks radiosonde yang digunakan dalam analisa udara atas untuk melihat labilitas udara, energi potensial untuk mendukung pertumbuhan awan konvektif serta peluang terbentuknya thunderstorm diantaranya sebagai berikut:

\subsubsection{K Index}

$\mathrm{K}$ Indeks (KI) merupakan suatu ukuran potensi badai akibat gerak konvektif yang diukur berdasarkan selang suhu vertikal dan kelembapan atmosfer. Nilai KI dihitung berdasarkan nilai suhu pada lapisan 850,700 , dan $500 \mathrm{mb}$ serta nilai suhu titik embun pada lapisan 850 dan 700 mb. Berikut adalah persamaan KI

$K I=T_{850}-T_{500}+T d_{850}-\left(T_{700}-T d_{700}\right)$

Dimana $\mathrm{T}$ merupakan suhu dan $\mathrm{Td}$ merupakan suhu titik embun. Semakin besar perbedaan suhu antara lapisan 850 dan $500 \mathrm{mb}$, maka semakin tinggi kelembapannya dan semakin besar nilai KI-nya. Jika nilai KI semakin besar maka semakin berpotensi terjadinya konveksi.

\subsubsection{Showalter Index}

Indeks ini digunakan untuk menentukan tingkat stabilitas atmosfer. Indeks ini juga biasa digunakan untuk menetukan potensi thunderstorm. Nilai Showalter Index dihitung dengan mengangkat parsel udara dari level $850 \mathrm{mb}$ ke level $500 \mathrm{mb}$ secara adiabatik. Selisih antara suhu parsel udara dengan suhu lingkungan di level $500 \mathrm{mb}$ ini disebut Showalter index.

\subsubsection{Lifted Index}

Lifted index merupakan modifikasi dari showalter index yang banyak dipakai untuk melihat kelabilan udara dalam kondisi konvektif frontal.

Nilai Lifted Index dihitung dengan mengangkat parsel udara dari level di dekat permukaan (setebal $50 \mathrm{mb}$ dari permukaan/ sekitar 30 feet) sampai dengan $500 \mathrm{mb}$ secara adiabatik. Selisih suhu parsel tersebut dengan suhu lingkungannya pada level $500 \mathrm{mb}$ disebut dengan Lifted Index.

\subsubsection{Convective Available Potential Energy (CAPE)}

Jumlah energi yang dibutuhkan oleh parsel udara untuk naik ke atmosfer. Secara efektif CAPE merupakan daya apung positif dari parsel udara dan merupakan indikator kelabilan atmosfer.

\subsection{Wilcoxon Signed Rank Test}

Wilcoxon signed rank test merupakan uji non parametrik yang digunakan untuk menganalisis data berpasangan karena adanya dua perlakuan yang berbeda (Pramana \& Mawardi, 2012). Wilcoxon signed rank test digunakan apabila 
data tidak berdistribusi normal. Dasar pengambilan keputusan untuk menerima atau menolak Ho pada uji wilcoxon signed rank test ini adalah sebagai berikut :

- Jika probabilitas (Asymp.Sig) < 0.05 maka Ho ditolak

- Jika probabilitas (Asymp.Sig) > 0.05 maka Ho diterima

Rumus yang digunakan untuk pengujian ini adalah:

$$
Z=\frac{T-\mu_{T}}{\sigma_{T}}
$$

Dimana:

$$
\begin{aligned}
& \mathrm{T}=\text { jumlah jenjang } \\
& \mu_{T}=\frac{n(n+1)}{4} \\
& \sigma_{T}=\sqrt{\frac{n(n+1)(2 n+1)}{24}}
\end{aligned}
$$

Untuk menghitung pengujian ini maka ada beberapa langkah yang perlu dilakukan, yaitu:

1. Berikan jenjang atau rank kepada tiap selisih dari pasangan ( $\mathrm{Y}-\mathrm{X})$ tanpa memperhatikan tanda negatif atau positif. Apabila terdapat dua atau lebih beda yang sama, maka dapat dikatakan bahwa jenjang untuk tiap-tiap selisih merupakan jenjang rata-rata.

2. Berikan tanda positif dan negatif kepada jenjang sesuai dengan tanda dari selisih tersebut

3. Jumlahkan semua jenjang positif dan negatif

4. Dari hasil penjumlahan nilai $T$ diatas, yang digunakan adalah nilai $T$ terkecil untuk dilakukan uji dengan perhitungan diatas dan bandingkan dengan tabel Z (Djarwanto, 2003).

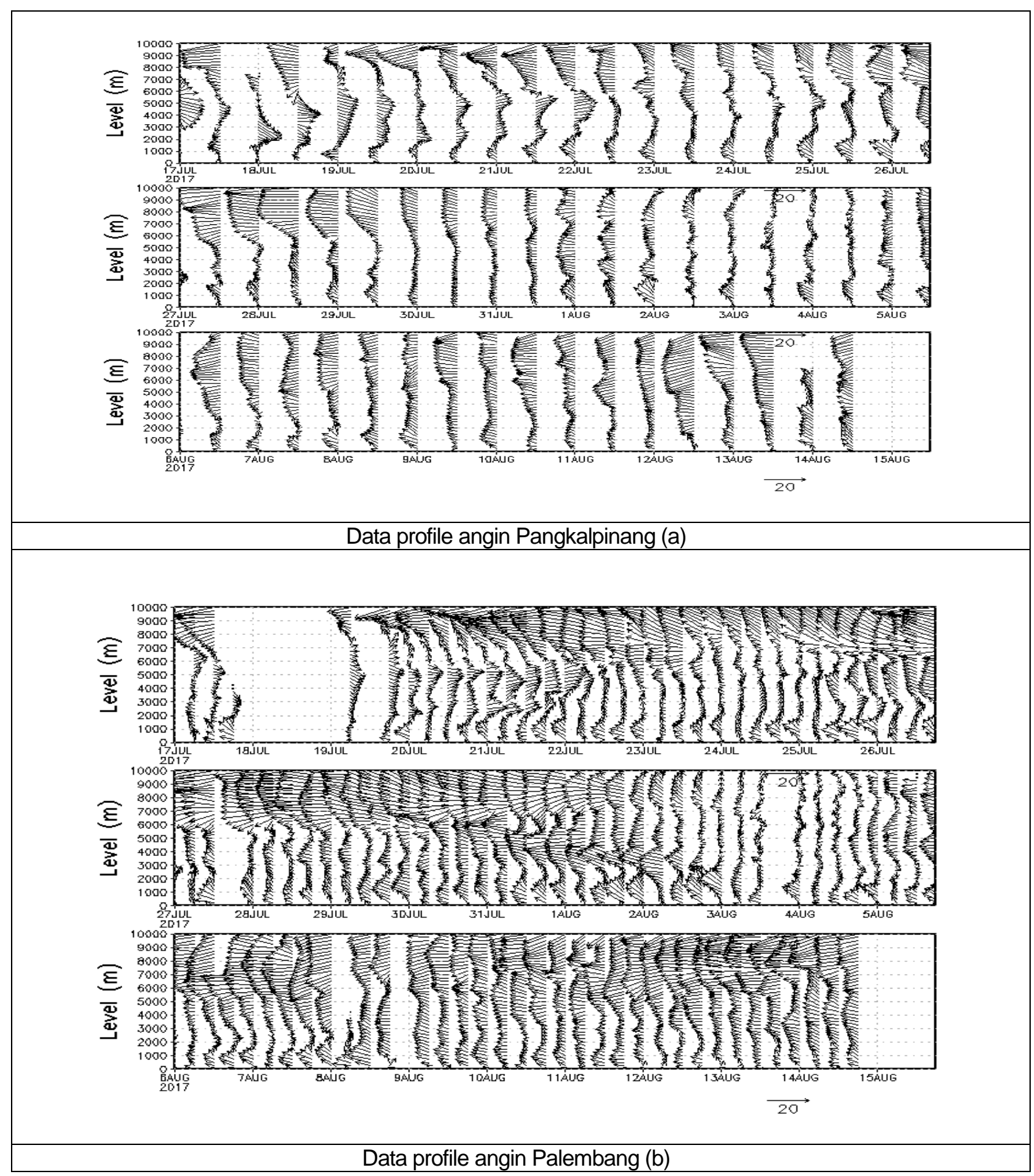

Gambar 2. Profile Angin Pangkalpinang (a) dan Palembang (b) (17 Juli - 16 Agustus 2018). 


\section{HASIL DAN PEMBAHASAN}

Pada bab ini akan menguraikan perbandingan pola parameter atmosfer dari hasil pengukuran radiosonde di Palembang dan Pangkalpinang selama dilaksanakan IOP. Banyaknya data yang digunakan sebagai perbandingan hanya 1 bulan dan pada saat tersebut angin dominan bertiup dari Timur - Tenggara (Gambar 2).

Gambar 3 memperlihatkan data global parameter atmosfer di Palembang dan Pangkalpinang yang perlu dianalisis terlebih dahulu sebelum melakukan analisis data soundingnya. Data global diambil dari data www.esrl.noaa.gov/psd/ dengan resolusi spasial 2.5 degree. Berdasarkan analisis data global tersebut $(\mathrm{RH}$, temperature dan wind) terlihat pola keadaan atmosfer di Palembang (longitude $104.42^{\circ} \mathrm{E}$ dan latitude $2.54{ }^{\circ} \mathrm{S}$ ) dan Pangkalpinang (longitude $106.08^{\circ} \mathrm{E}$ dan latitude $2.10^{\circ} \mathrm{S}$ ) memiliki kemiripan pada periode $17 \mathrm{Juli}-16$ Agustus 2017, hal ini disebabkan karena data tersebut memiliki resolusi spasial 2.5 derajat.
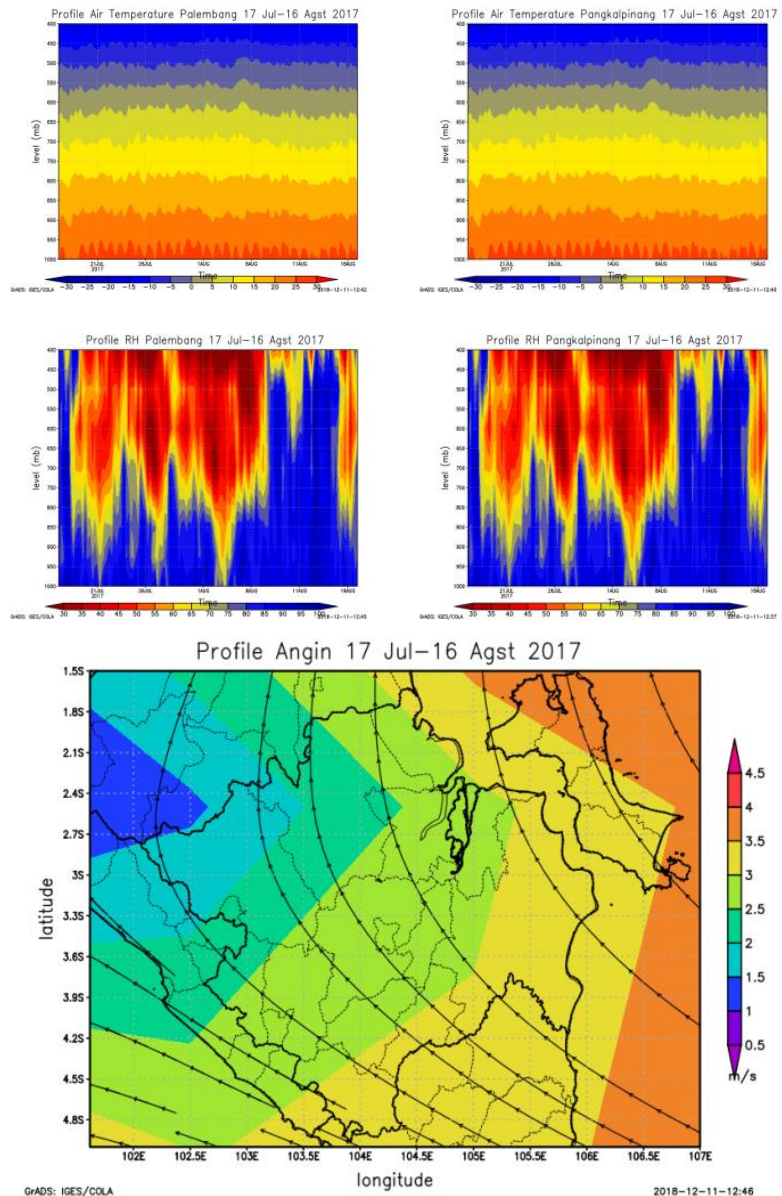

Gambar 3. Analisis Global Parameter Atmosfer di Palembang dan Pangkalpinang (sumber : https://www.esrl.noaa.gov/psd/)

Selanjutnya dilakukan analisis data pengukuran sinoptik di Palembang dan Pangkalpinang. Data pengukuran tersebut bersumber dari data pengukuran di stasiun meteorologi Palembang dan Pangkalpinang yang dapat diambil dari http://ogimet.com/. Hasil observasi permukaan (Temperatur, $\mathrm{RH}$, Tekanan) juga memperlihatkan kondisi cuaca di Palembang dan Pangkalpinang sebagian besar memiliki kemiripan, kecuali data tekanan permukaan pada tanggal 25 Juli yang terlihat berbeda jika dibandingkan data permukaan pada tanggal sebelum dan setelahnya (dapat dilihat pada gambar 4).

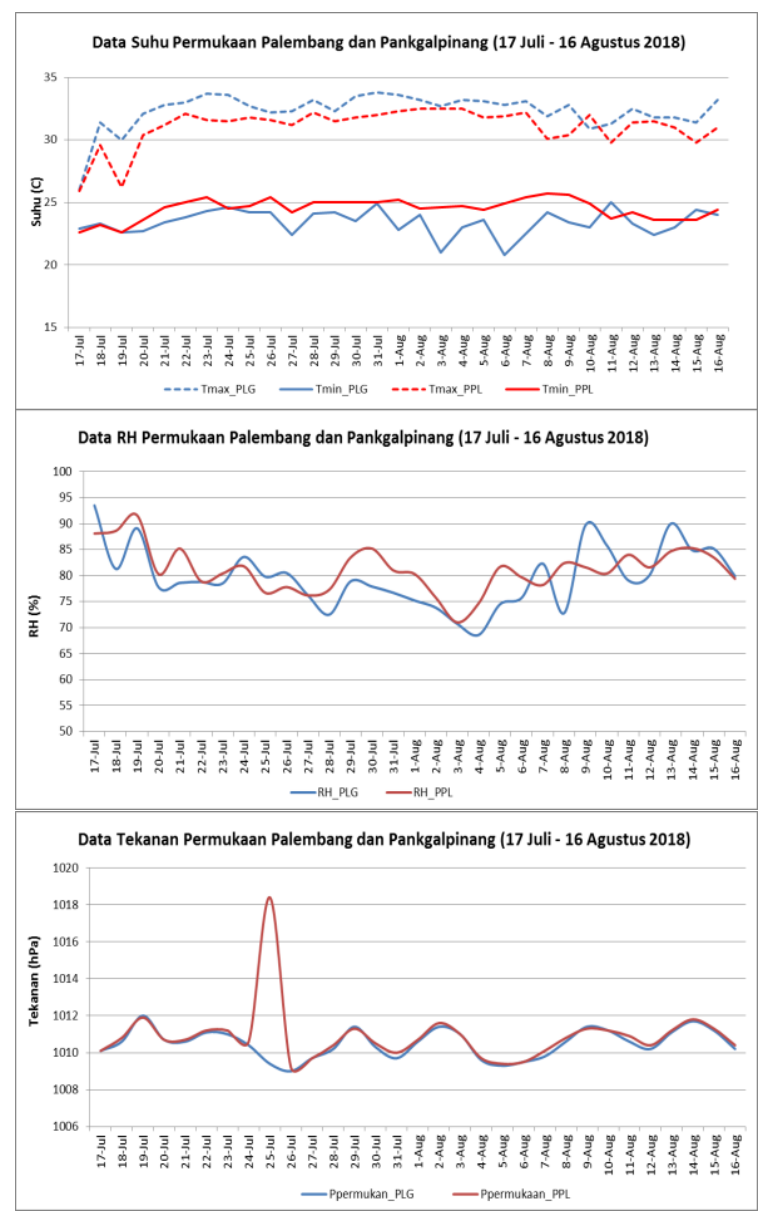

Gambar 4 Analisis Sinoptik di Palembang dan Pangkalpinang (sumber : http://ogimet.com/)

Setelah mengetahui hasil analisis kondisi cuaca di kedua tempat pada periode 17 Juli 16agustus 2017, selanjutnya dapat dilakukan proses perbandingan data dengan menggunakan data Sounding. Proses perbandingan data yang pertama dilakukan dengan visual yaitu melihat pola hasil di kedua lokasi dalam grafik untuk tiap-tiap parameter. Selanjutnya perbandingan dilakukan melalui pengujian statistik Wilcoxon Signed Rank Test.

Perbandingan secara visual untuk tiap parameter dari Palembang dan Pangkalpinang ditunjukkan pada gambar 5. Parameter dengan nomor 1 menunjukkan parameter atmosfer dari Palembang dan nomor 2 menunjukkan parameter atmosfer dari Pangkalpinang. Dari grafik tersebut terlihat semua parameter meliputi K Index, Lifted Index, Showalter Index, Convective Temperature (Tc), CAPE, RH 850 mb,RH 700 mb dan RH 500 mb memiliki pola yang mirip dan hampir sama. 


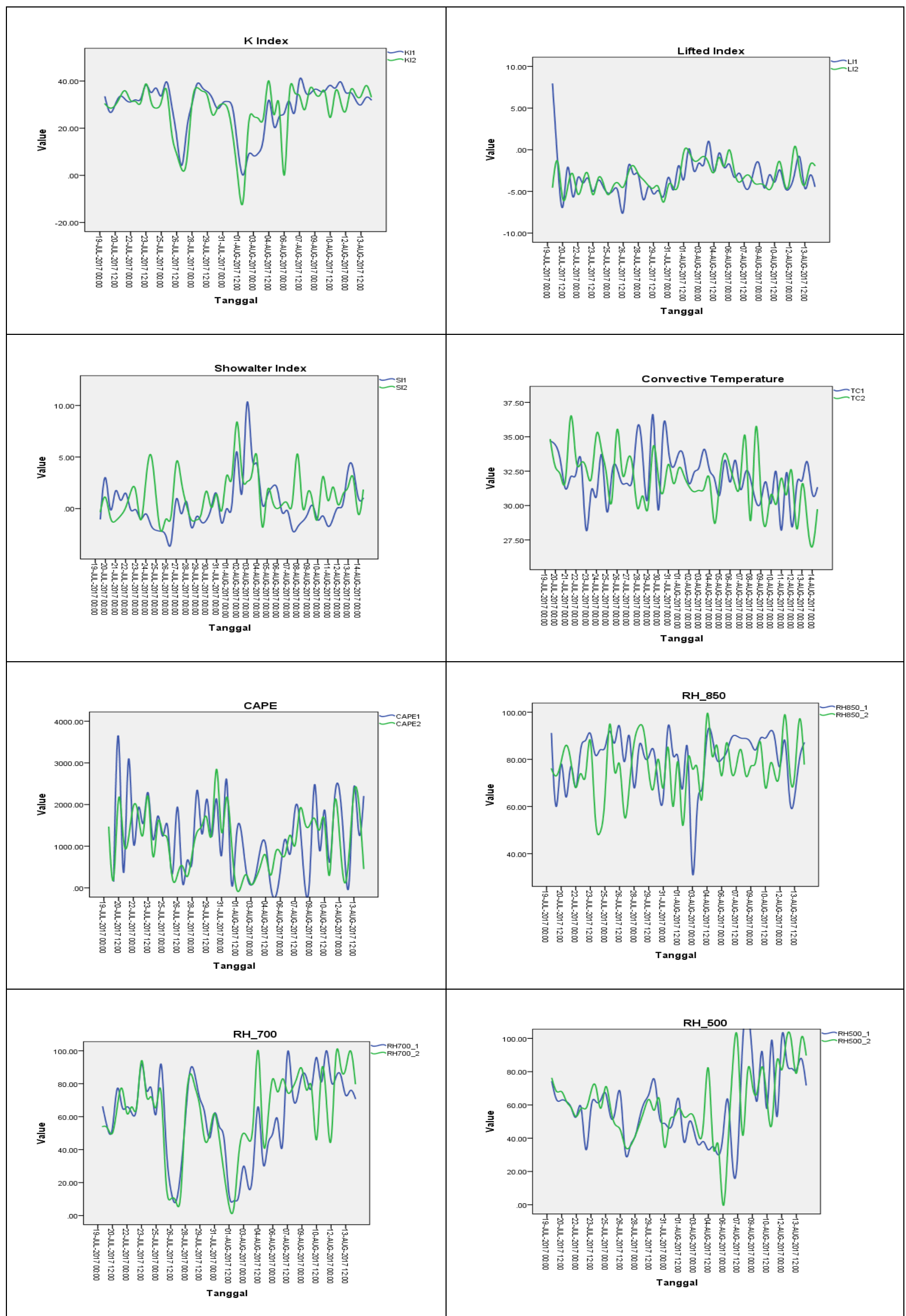

Gambar 5. Grafik perbandingan parameter dari radiosonde Palembang (1) dan Pangkalpinang (2). 
Tabel 1. Hasil uji statistik Wilcoxon Signed Rank Test Test Statisticsa

\begin{tabular}{|c|c|c|c|c|c|c|c|c|}
\hline & LI2 - LI1 & $\mathrm{KI} 2-\mathrm{KI} 1$ & SI2 - SI1 & TC2 - TC1 & $\begin{array}{l}\text { CAPE2 - } \\
\text { CAPE1 }\end{array}$ & $\begin{array}{l}\mathrm{RH} 850 \_2- \\
\mathrm{RH} 850 \_1\end{array}$ & $\begin{array}{l}\mathrm{RH} 700 \_2- \\
\mathrm{RH} 700 \_1\end{array}$ & $\begin{array}{l}\mathrm{RH} 500 \_2- \\
\mathrm{RH} 500 \_1\end{array}$ \\
\hline $\begin{array}{l}\text { Z } \\
\text { Asymp. Sig. (2-tailed) }\end{array}$ & $\begin{array}{r}-1.594^{b} \\
.111\end{array}$ & $\begin{array}{r}-1.567^{c} \\
.117 \\
\end{array}$ & $\begin{array}{r}-2.636^{b} \\
.008\end{array}$ & $\begin{array}{r}-1.266^{c} \\
.205\end{array}$ & \begin{tabular}{r|}
$-1.161^{c}$ \\
.246 \\
\end{tabular} & $\begin{array}{r}-1.908^{\mathrm{c}} \\
.056\end{array}$ & $\begin{array}{r}-.294^{\mathrm{b}} \\
.769\end{array}$ & $\begin{array}{r}-.981^{\mathrm{b}} \\
.326\end{array}$ \\
\hline
\end{tabular}

a. Wilcoxon Signed Ranks Test

b. Based on negative ranks.

c. Based on positive ranks.

Selanjutnya akan dilakukan pengujian secara statistik dengan metode Wilcoxon signed rank test, dengan hipotesis adalah sebagai berikut:

$\mathrm{H}_{0}$ : Tidak terdapat perbedaan yang signifikan antara nilai parameter radiosonde Palembang dan Pangkalpinang

$\mathrm{H}_{1}$ : Terdapat perbedaan yang signifikan antara nilai parameter radiosonde Palembang dan Pangkalpinang dengan level of significant sebesar $5 \%$ dan kriteria pengujian $\mathrm{H}_{0}$ ditolak apabila nilai probabilitas $<0.05$.

Dari Tabel 1 dapat diketahui nilai probabilitas dari tiap-tiap parameter dalam baris (Asymp. Sig (2tailed)). Dari tabel tersebut diketahui untuk parameter Lifted Index, $\mathrm{K}$ Index, Convective Temperature (Tc), CAPE, RH $850 \mathrm{mb}, \mathrm{RH} 700 \mathrm{mb}$, $\mathrm{RH} 500 \mathrm{mb}$ nilai probabilitasnya $>0.05$ sehingga dapat dikatakan kalau parameter tersebut tidak ada perbedaan untuk kedua lokasi sedangkan parameter Showalter Index (SI) memiliki nilai probablitas 0.008 yang berarti $<0.05$ sehingga dapat dikatakan terdapat perbedaan parameter Showalter Index untuk Radiosonde Palembang dan Pangkalpinang. Perbedaan Showalter index tersebut disebabkan karena adanya pengaruh parameter temperatur lingkungan maupun parsel udara di level $850 \mathrm{mb}$, dimana diketahui bahwa formula untuk mendapatkan nilai indeks ini diperoleh dengan mengetahui selisih temperatur lingkungan pada level $500 \mathrm{mb}$ dan temperatur pengangkatan parsel udara adiabatik dari level $850 \mathrm{mb}$ hingga level $500 \mathrm{mb}$. Jika ditulis dalam formula matematika (Showalter, 1953) seperti berikut:

$$
S I=T_{500 h P a}-T_{850 h P a-500 h P a}
$$

Palembang dan Pangkalpinang memiliki ratarata ketinggian dataran rendah yang sedikit berbeda. Berdasarkan data statistik yang diperoleh ada perbedaan kurang lebih 30mdpl antara Palembang dan Pangkalpinang. Perbedaan rata-rata ketinggian dataran rendah ini dapat mengakibatkan adanya perbedaan temperatur pada level $850 \mathrm{mb}$.

\section{KESIMPULAN}

Hasil perbandingan parameter untuk pengukuran radiosonde di Palembang dan Pangkalpinang secara visual grafik untuk masingmasing parameter menunjukkan hasil yang mirip atau berdekatan dalam grafiknya, sedangkan dari pengujian Wilcoxon Signed Rank Test dapat diketahui bahwa parameter K Index, Lifted Index,
Tc, CAPE dan RH untuk lapisan mandatory dapat dikatakan sama atau tidak ada perbedaan yang signifkan. Parameter yang terdapat perbedaan signifikan adalah parameter Showalter Index.

Hasil penelitian ini dapat mendukung dan menjelaskan bahwa penggunaan radiosonde dari wilayah Pangkalpinang cukup representatif untuk menggambarkan keadaan atmosfer di wilayah Palembang. Namun perlu juga dibandingkan pada bulan-bulan tertentu dimana arah angin di wilayah Palembang berasal dari utara seperti pada musim hujan, apakah radiosonde dari Pangkalpinang tersebut masih cukup representatif untuk menggambarkan wilayah Palembang.

\section{DAFTAR PUSTAKA}

Aprilina, K., Nuraini, T.A., Sopaheluwakan, A. (2017). Kajian Awal Uji Statistik Perbandingan Suhu Udara dari Peralatan Otomatis dan Manual. Jurnal Meteorologi dan Geofisika, 18(1), 13-20.

Djarwanto. (2003). Statistika Nonparametrik. Yogyakarta: BPFE Yogyakarta.

Juaeni, I. (2017). Penerapan Metode Anova1 Untuk Perbandingan Parameter Atmosfer Permukaan Antara Padang dan Selaparang. Jurnal Meteorologi dan Geofisika, 18(2), 73-81.

Mayangwulan, D., Wiratmo, J., Siregar, P.M. (2011). Potensi Kejadian Badai Guntur Berdasarkan Parameter Kelembapan, Labilitas Udara dan Mekanisme Pengangkatan (Studi Kasus: Di Bandar Udara Frans Kaisiepo Biak). Jurnal Sains Dirgantara, 8(2), 139-156.

Ogungbenro, S.B., Morakinyo, T.E. (2014). Rainfall Distribution and Change Detection Across Climatic Zones in Nigeria. Weather and Climate Extremes, 5-6(1-6). doi: 10.1016/j.wace.2014.10.002

Pramana, A., Mawardi, W. (2012). Analisis Perbandingan Trading Volume Activity dan Abnormal Return Saham Sebelum dan Sesudah Pemecahan Saham. Skripsi. Fakultas Ekonomika dan Bisnis. Universitas Diponegoro Semarang.

Showalter, A.K. (1953). A Stability Index for Thunderstorm Forecasting. Bulletin of the American Meteorology Society, 34(6), 250 252.

Syaifullah, M.D. (2011). Potensi Atmosfer dalam Pembentukan Awan Konvektif pada 
Pelaksanaan Teknologi Modifikasi Cuaca Di DAS Kota Panjang dan DAS Singkarak 2010. Jurnal Sains \& Teknologi Modifikasi Cuaca, 12(1), 9-16.

Syaifullah, M.D. (2017). Analisis Kondisi Udara Atas Wilayah Indonesia dengan Data Radiosonde. Jurnal Meteorologi dan Geofisika, 18(1), 1-12.

Hua, W., Yang, K-Q., Fan, G-Z. (2017). Uncertainty in Hottest Years Ranking:
Analysis of Tibetan Plateau Surface Air Temperature. Atmospheric and Oceanic Science Letter, 10(4), 337-341. doi: 10.1080/16742834.2017.1330646.

Zahroh, N.F., Puspa Dewi, N.W.S., Harsanti, D. (2017). Indeks Labilitas Udara Untuk Memprediksi Kejadian Badai Guntur pada Puncak Musim Hujan Tahun 2016. Jurnal Sains \& Teknologi Modifikasi Cuaca, 18(1), 9-15. doi: 10.29122/jstmc.v18i1.1764 